\title{
Petrography and Geochemistry of Baïbokoum-Touboro-Ngaoundaye Granitoids on the Chad-Cameroon-RCA Borders (Adamawa-Yade Domain)
}

\author{
Naïmou Seguem 1* ${ }^{*}$ Mbaguedjé Diondoh', Amadou Diguim Kepnamou' ${ }^{2}$, \\ Ntoumbé Mama², Mabrouk Sami ${ }^{3}$, Ganwa Alembert Alexandre2,4, \\ Ekodeck Georges Emmanuel ${ }^{5}$
}

\begin{abstract}
${ }^{1}$ Department of Geology, Faculty of Sciences and Techniques, University Adam Barka of Abeche, Abeche, Chad
${ }^{2}$ Department of Mines and Geology, School of Geology and Mining Engineering, University of Ngaoundere, Meiganga, Cameroon ${ }^{3}$ Department of Geology, Faculty of Sciences, Minia University, El-Minia, Egypt

${ }^{4}$ Department of Earth Sciences, Faculty of Sciences, University of Ngaoundere, Ngaoundere, Cameroon

${ }^{5}$ Department of Earth Sciences, Faculty of Sciences, University of Yaounde I, Yaounde, Cameroon

Email: ^naimouseguem@yahoo.fr
\end{abstract}

How to cite this paper: Seguem, N., Diondoh, M., Kepnamou, A.D., Mama, N., Sami, M., Alexandre, G.A. and Emmanuel, E.G. (2022) Petrography and Geochemistry of Baibokoum-Touboro-Ngaoundaye Granitoids on the Chad-Cameroon-RCA Borders (Adamawa-Yade Domain). Open Journal of Geology, 12, 136-155.

https://doi.org/10.4236/ojg.2022.122007

Received: December 26, 2021

Accepted: February 21, 2022

Published: February 24, 2022

Copyright $\odot 2022$ by author(s) and Scientific Research Publishing Inc. This work is licensed under the Creative Commons Attribution-NonCommercial International License (CC BY-NC 4.0). http://creativecommons.org/licenses/by-nc/4.0/ (c) (i) (s) Open Access

\begin{abstract}
The Baibokoum-Touboro-Ngaoundaye area is located in the Adamoua-Yade domain of the Pan-African Fold Belt in Central Africa. The present work concerns the petrographic and geochemical study. The study area is made up of plutonic rocks including two amphibole granites, four biotite and muscovite granites, two syenites and one monzonite sample. These rocks have a granular porphyroid texture, with a mylonitic tendency. The primary paragenesis consists of $\mathrm{Opx}+\mathrm{Cpx}+\mathrm{Amp}+\mathrm{Bt}+\mathrm{Pl}+\mathrm{Or}+\mathrm{Mic}+\mathrm{Qtz}+\mathrm{Ap}+\mathrm{Sph}$ $+\mathrm{Zr}$ and the secondary paragenesis consisting of $\mathrm{Ch}+\mathrm{Op}$. Plutonic rocks are shoshonitic to calc-alkaline with a strong potassic affinity. The REE profiles of these rocks show a negative anomaly of $\mathrm{Eu}$ in the granites and no Eu anomaly in syenites and monzonite (syeno-diorite). Multielement spectra of plutonic rocks present a negative anomaly in $\mathrm{Nb}-\mathrm{Ta}$ and $\mathrm{Ti}$. Fractional crystallization is the process that made these rocks of study area. These rocks are placed in a subduction to syn-collisional (VAG + Syn-COLG) and of intraplate granitoids (WPG) environment.
\end{abstract}

\section{Keywords}

Petrography, Geochemistry, Baïbokoum-Touboro-Ngaoundaye, Adamawa-Yade Domain, Pan-African Fold Belt 


\section{Introduction}

The Baïbokoum-Touboro-Ngaoundaye area belongs to the Adamawa-Yade Domain of the Pan-African Fold Belt of Central Africa (Figure 1). The Adamawa domain is located in central Africa and cross over central Cameroon, Southern Chad and Northwestern Central African Republic and continues to Sudan. The Adamawa-Yade domain is characterized by the abundance of granitoids and the presence of major accidents. One of its accidents is the Central African Shear Zone in Cameroon as the Center Shear Cameroonian and continues to Sudan at the level of the Baggara basin (Figure 2). Previous works [1] and [2] show that the study area is located between two shear branches which intersected at the level of Banyo: the Tchollire-Banyo Shear Zone (N50E) and the Central Cameroonian Shear Zone (N70E). The Yaounde domain continues in the Bozoum and Nde area in the North of the Central African Republic. The geological works carried out in the Adamawa-Yade domain are unevenly distributed and geologically discontinuous. In addition, within countries, research does not respect geological limits, but is subject to state limits. Many works have been done in this Adamawa-Yade domain, for example in Cameroon [1] [3] [4] [5] and previous works are very old in southern Chad [6]-[11] and the North of the Central African Republic [12] and some studies have been carried out on the Tchollire-Banyo shear [13]

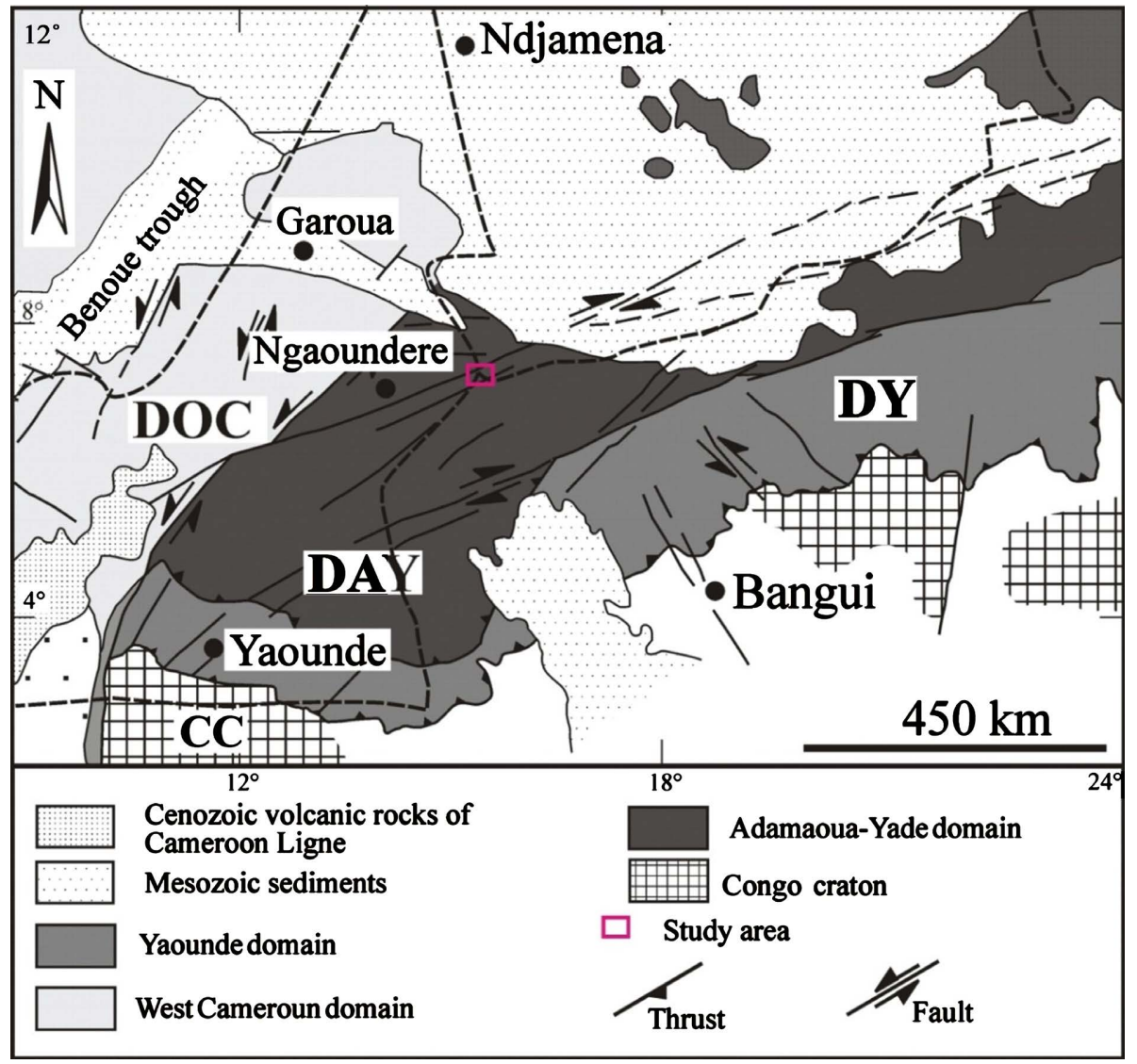

Figure 1. Geological sketch of the Pan-African fold belt of the north Congo craton showing the study area (simplified after [3]). 


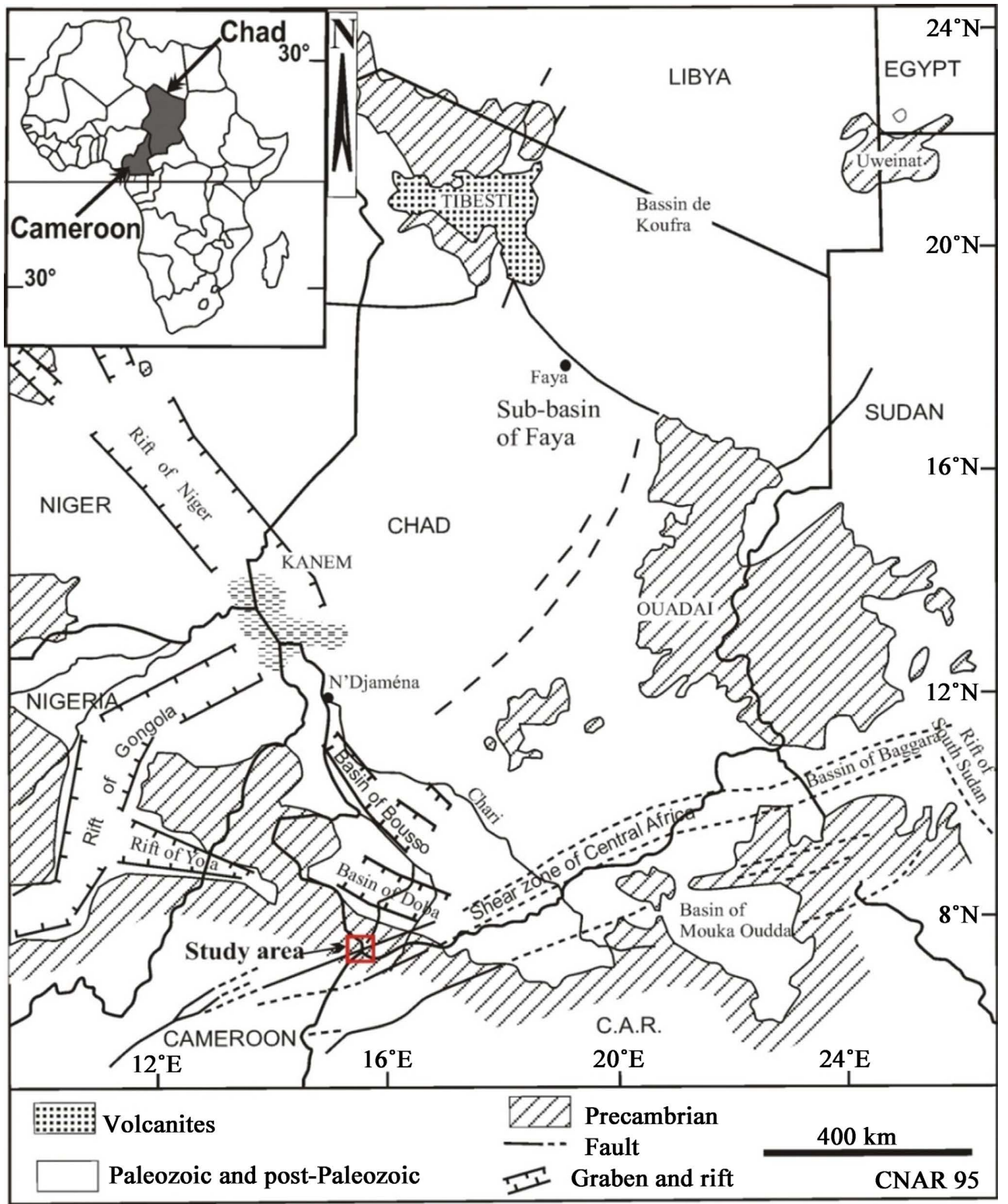

Figure 2. Geological sketch of Chad, North Cameroon and North-West of the CAR (Central African Republic) (simplified after [19]) showing the location of the study area.

[14] [15]. Despite its studies, none have been carried out simultaneously in the Baibokoum-Touboro-Ngaoundaye area on the Chad-Cameroon-Central African border. Thus, the present work aims to contribute to the understanding of the geodynamic evolution of the Adamawa-Yade Domain in particular and the Pan-African Fold Belt of Central Africa in general, by petrographical and geochemical study of granitoids from the tri-junction border area.

\section{Geological Setting}

The Baïbokoum-Touboro-Ngaoundaye area belongs to the Pan-African Fold Belt of Central Africa. This pan-African Fold Belt of Central Africa constitutes a large geological complex located in the north of Congo craton. It crosses over 
Cameroon, the Central African Republic, Chad and is believed to extend into Sudan [16]. The Cameroon, Central African Republic and Chad are largely made up of formations from the Pan-African mobile zone [16] This mobile zone stretches from the Saharan Metacraton [17] in the North, to the Congo Craton in the South and from East to West, from the West African Craton to the Pan-African of the East Africa [16]. The Baibokoum-Touboro-Ngaoundaye area is part of the Adamawa-Yade domain of the Pan-African fold belt of Central Africa [3] (cf. Figure 1) and is made up of Precambrian formations [18]. According to [18], this region is crossed by the Central African Shear Zone (Figure 2). It is made up of several petrographic types [10] (Figure 3).

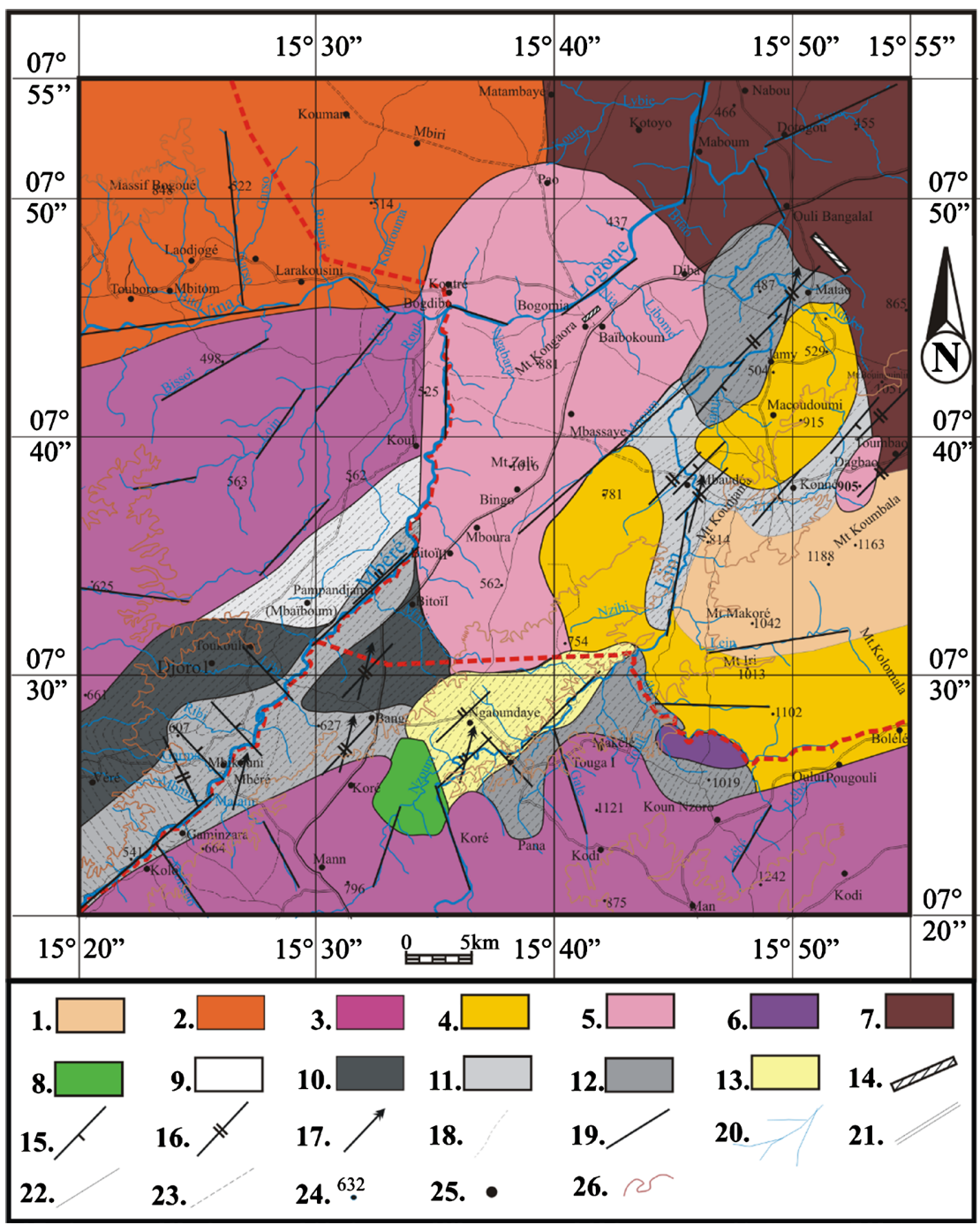

1. Amphibole and biotite granite; 2 . Amphibole granite; 3 . Biotite and muscovite granite; 4. Biotite granite; 5. Syenite; 6. Monzonite; 7. Granodiorite; 8. Amphibolite; 9. Pyroxene and garnet gneiss; 10. Garnet and amphibole gneiss; 11. Amphibole and biotite gneiss; 12. Biotite gneiss; 13. Schist; 14. Quartzite; 15. Foliation; 16. Schistosity; 17. Lineation; 18. S2 schistosity trajectory; 19. Fracturing; 20. Hydrographic Network; 21. Main road; 22. Secondary road; 23. Track; 24. Spot Height; 25. Villages; 26. Contour level.

Figure 3. Geological map of the Baïbokoum-Touboro-Ngaoundaye area. 


\section{Methodology}

The determination of different rocks types observed in the field has been made deeper through the use of a polarizing light microscope. For the geochemical studies, nine (09) rock samples were selected, including two amphibole granites, four biotite and muscovite granites, two syenites and one mozonite (syeno-diorite). The characterization of the major, trace and rare earth elements of these analyzed samples was determined by the ICP-AES (Inductively Coupled Plasma-Atomic Emission Spectroscopy) quantification technique at ACME Analytical Laboratories (Vancouver, Canada).

\section{Results}

\subsection{Petrography}

The Baibokoum-Touboro-Ngaoundaye regions are made up of granites, syenites and monzonite.

\subsubsection{Granites}

\section{1) Amphibole granite}

The amphibole granite forms a chaotic-looking outcrop, elongated hills ENE-WSW in the Department of Mayo-Rey in Touboro. The blocks are decimetric to decametric in size (Figure 4(a)). At the level of the Vina river, the amphibole granite outcrops as a slab and contains enclaves of amphibolite. The rocks have a pinkish color.

Microscopic observations show granular porphyritic texture (Figure 4(b)) and consist of amphibole, orthoclase, microcline, plagioclase, quartz, sphene, apatite and opaque minerals.

Amphibole is a green hornblende that forms elongated sections of 1 to $4 \mathrm{~mm}$ long and 0.5 to $1 \mathrm{~mm}$ wide. It represents $10 \%$ of the rocks. The elongated sections display single Carlsbad twinning. It contains inclusions of opaque minerals and apatite. Orthoclase (about 20\%) forms elongated crystals of up to $5 \mathrm{~mm}$ long and $2 \mathrm{~mm}$ wide. It is regularly perthitic with exsolutions in bands. Orthoclase crystals have myrmekite buds at their edges. Orthoclase is associated with plagioclase. Microcline (about 15\%) forms elongated crystals $7.5 \mathrm{~mm}$ long and 2.5 $\mathrm{mm}$ wide. It displays polysynthetic twinning of albite and pericline which gives it a shimmering grid. It is associated with plagioclase, quartz, orthoclase and opaque minerals. Plagioclase makes up $25 \%$ of the volume of the rock. It forms small crystals compared to orthoclase (on average $3 \mathrm{~mm}$ long and $1 \mathrm{~mm}$ wide). Small crystals of plagioclase are also found included in the orthoclase. Plagioclase is often zoned with 3 to 4 concentric zones. This zoning is materialized by a differential distribution of submicroscopic inclusions in the mineral. Plagioclase shows myrmekite buds at its edges. Quartz (about 20\%) forms polycrystalline mineral with rolling extinction. It contains trails of submicroscopic fluid inclusions perpendicular to the elongation of the crystals. The sphene forms subautomorphic crystals of $0.2 \mathrm{~mm}$ on average. It is arranged in a chain about $3 \mathrm{~mm}$ 
long at the level of the rock. Accessory minerals (approximately 10\%) are represented by sphene, apatite and opaque minerals.

\section{2) Biotite and muscovite granite}

The biotite and muscovite granite form hills respectively in the villages of Mbidere to the NW and Tougal SE of the study area. These hills present a chaotic aspect, with decimetric to decametric blocks. Some of Mbidere blocks contain in places enclaves of amphibole and biotite gneiss. The biotite and muscovite granite also outcrops as a slab in the savannah and also contains enclaves of migmatitic gneiss at Koré (Figure 4(c)). It sometimes outcrops in stream beds and at the foot of certain hills. It has a dark gray weathering patina. Microscopic observation shows a granular porphyroid texture and is mylonitized in given areas. The rock is composed of $6-8 \mathrm{~mm}$ orthoclase phenocrysts, in a grainy matrix made of biotite, muscovite, plagioclase, microcline, quartz, zircon, apatite and opaque minerals. Biotite (7\%) forms dark brown flakes of $1.5 \mathrm{~mm} \times 0.2 \mathrm{~mm}$ to $2 \mathrm{~mm} \times 0.4 \mathrm{~mm}$. It often turns into chlorite with cleavages thickened by the concentration of opaque minerals. Its borders are corroded by alkaline feldspars, plagioclase, quartz and muscovite. It is sometimes associated with muscovite (Figure 4(d)). Muscovite (8\%) forms elongated flakes $2.5 \mathrm{~mm}$ long and $1.3 \mathrm{~mm}$ wide on average, associated with other rock minerals. There are two types of muscovites (primary muscovite (Ms1) and secondary muscovite (Ms 2)). Secondary muscovite results from the phenomenon of feldspars alteration. Orthoclase $(25 \%)$ forms subautomorphic crystals with a cloudy appearance due to submicroscopic inclusions. We also notice a phenomenon of feldspar alteration to muscovite at the fracturing planes of the mineral. The size of the crystals in the grainy matrix of the rock varies from $0.7 \mathrm{~mm}$ to $1.5 \mathrm{~mm}$. It has cracked sections in which small quartz crystals crystallize. Orthoclase crystals have myrmekite buds at their edges. It is poorly represented compared to plagioclases. Plagioclase (about 15\%) forms subautomorphic to xenomorphic crystals $4.5 \mathrm{~mm}$ long on average. Plagioclases are often affected by microfractures which cause twins of the mineral to shift a little. These polysynthetic twins are sometimes blurry in places and end as a bevel in the mineral. The microcline represents $20 \%$ of the volume of the rock. It shows a very fine and almost subrectangular shimmering grid. It is sometimes surrounded by small crystals of quartz and plagioclase. Quartz (about 15\%) forms automorphic to subautomorphic crystals of variable size from 0.3 to $2 \mathrm{~mm}$. It is also found in small crystals around feldspars. Accessory minerals (approximately 10\%) are zircon, apatite, and opaque minerals.

\subsubsection{Syenite}

The syenite forms elongated hills WSW-ENE from Bingo village to Baibokum. It outcrops in the form of blocks on the hills (Figure 4(e)). The syenite shows large blocks scattered throughout the landscape from Mbaissaye to Libome (Yoli) passing through Baïbokoum. It sometimes outcrops as a slab around the village of Dagbao. This rock has a gray color with a dark gray weathering patina. The rock has a granular porphyroid texture. It is composed of pyroxene, amphibole, 

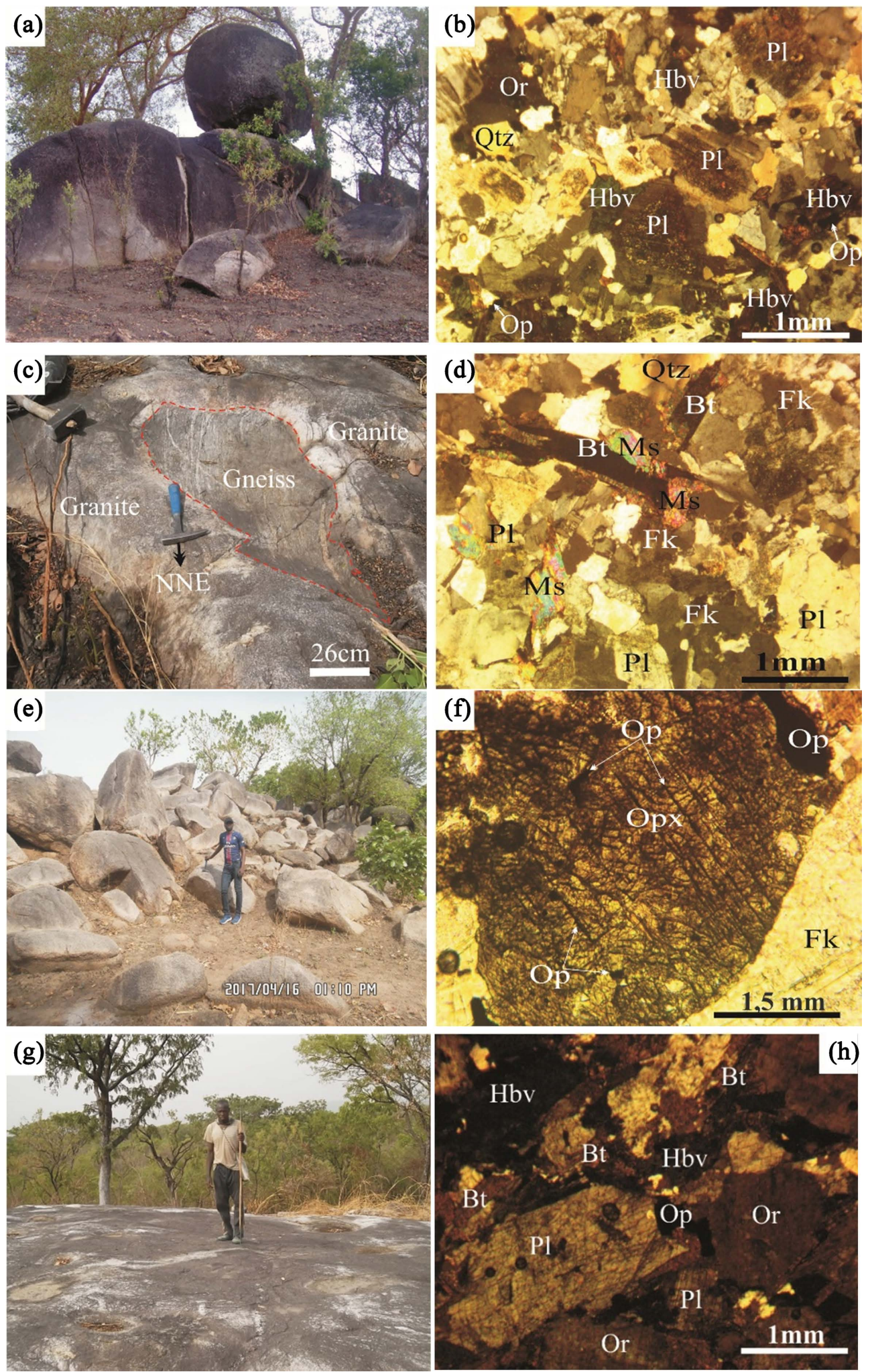

Figure 4. (a) Blocks outcrop at Touboro; (b) Granular porphyroid texture in the granite at Touboro; (c) Enclave of gneiss in the 2 micas granite; (d) Biotite associated with muscovite to present the schistosity; (e) Outcrop in blocks of syenite at Baïbokoum; (f) Association of opaque minerals along orthopyroxene cleavages in the syenite; (g) Slab outcrop of monzonite; (h) Granular porphyroid texture in monzonite. 
biotite, orthoclase, more or less quartz, sphene, zircon, apatite and opaque minerals. Pyroxene (approximately 7\%) consists of orthopyroxene and clinopyroxene. Orthopyroxene is characterized by its first order polarization tint and the presence of a very fine additional cleavage (010). Clinopyroxene is recognized by its vivid second order polarization color. Both types of pyroxenes have cleavages thickened by concentrations of opaque minerals (Figure 4(f)). Amphibole (about 10\%) is a green hornblende varying in size from 1.3 to $3.5 \mathrm{~mm}$. It grows on the edges and along the pyroxene cleavages. Amphibole is always associated with pyroxenes and biotite. Biotite (about $8 \%$ ) forms brown to dark brown flakes measuring $1.3 \mathrm{~mm} \times 0.5 \mathrm{~mm}$ on average. Biotite occurs under two habits. The first consists of flakes associated with quartz and feldspar in the grainy matrix of the rock. These flakes have cleavages thickened by concentrations of opaque minerals. This biotite often contains zircon inclusions. The second habit is represented by light brown biotite associated with amphibole. These biotites are arranged along the cleavages of the amphibole, which are planes of weakness allowing the circulation of fluids. Orthoclase (about 35\%) forms elongated slats of $4 \mathrm{~mm} \times 1.5 \mathrm{~mm}$ on average. All the crystals are perthitic with strips of exsolutions perpendicular to the mineral's elongation.

Plagioclase (about 25\%) forms crystals smaller than that of orthoclase and occurs only in the grainy bottom of the rock. It presents in places fine and irregular twins. It is sometimes affected by micro cracks which shift the twins of the mineral. Quartz forms subautomorphic crystals associated with other minerals in the rock matrix. Quartz (about 3\%) forms small crystals in the interstices between the orthoclase slats. Some quartz patches show a slight rolling extinction. Sphene forms crown around opaque minerals. It is generally associated with green hornblende and biotite. Opaque minerals form patches associated with amphibole. They are also found in inclusion in the latter. Zircon is generally included in biotite. The accessory minerals (about 12\%) in this rock are: apatite, sphene and zircon.

\subsubsection{Monzonite}

The monzonite forms small hills located to the SE of the study area. It outcrops as a slab in the savannah and sometimes at the foot of certain hills (Figure 4(g)). This rock is dark gray in color with a black weathering patina. The rock has a granular porphyroid texture (Figure 4(h)). It is composed of amphibole, biotite, quartz, orthoclase, plagioclase and opaque minerals.

Amphibole (10\%) is a green hornblende of 1 to $3 \mathrm{~mm}$ in length. It associates with biotite to materialize the schistosity of the rock. The amphibole changes to give biotite. Biotite (10\%) forms small light brown flakes of dimension $0.4 \mathrm{~mm} \times$ $0.2 \mathrm{~mm}$ on average. It associates with the amphibole to materialize the schistosity of the rock. Biotite is well crystallized in shadows under pressure from alkali feldspar.

Alkaline feldspar is primarily orthoclase $(30 \%-35 \%)$ which forms subautomorphic crystals. It is often associated with amphibole, plagioclase and opaque 
minerals. Plagioclase (25\% - 30\%) forms subautomorphic to xenomorphic crystals $4.5 \mathrm{~mm}$ long on average. The mineral of this plagioclase is often shifted by the microfractures which affect cause a small shift of the twins of the rock. These polysynthetic twins are sometimes blurry in places and end as a bevel in the mineral. Opaque minerals (15\%) occupy along the cleavages of amphiboles.

\subsection{Geochemistry}

Chemical analyses of the studied rock samples are given in Table 1.

Table 1. Major (wt\%) and trace element content (ppm) content in the Baibokoum-Touboro-Ngaoundaye Granitoids.

\begin{tabular}{|c|c|c|c|c|c|c|c|c|c|}
\hline \multirow{2}{*}{ Sample } & \multicolumn{2}{|c|}{ Amphibole granite } & \multicolumn{4}{|c|}{ Biotite and muscovite granite } & \multicolumn{2}{|c|}{ Syenite } & \multirow{2}{*}{$\begin{array}{c}\text { Monzonite } \\
\text { MAK2 }\end{array}$} \\
\hline & TOB & TOBP & TOUG1 & TOUG2 & MBID1 & KO3 & Bai & G & \\
\hline $\mathrm{SiO}_{2}$ & 65.62 & 67.78 & 75.29 & 71.35 & 72.54 & 75.22 & 62.39 & 62.31 & 55.03 \\
\hline $\mathrm{TiO}_{2}$ & 0.48 & 0.32 & 0.12 & 0.26 & 0.21 & 0.08 & 0.83 & 0.83 & 1.32 \\
\hline $\mathrm{Al}_{2} \mathrm{O}_{3}$ & 15.79 & 16.31 & 13.68 & 14.49 & 13.90 & 13.29 & 15.92 & 14.06 & 17.58 \\
\hline $\mathrm{Fe}_{2} \mathrm{O}_{3}$ & 3.39 & 2.38 & 1.17 & 1.61 & 1.45 & 1.08 & 3.80 & 4.64 & 8.00 \\
\hline $\mathrm{MnO}$ & 0.07 & 0.05 & 0.04 & 0.03 & 0.01 & 0.03 & 0.05 & 0.07 & 0.09 \\
\hline $\mathrm{MgO}$ & 1.38 & 0.69 & 0.06 & 0.29 & 0.16 & 0.03 & 1.99 & 3.13 & 2.71 \\
\hline $\mathrm{CaO}$ & 2.70 & 2.12 & 1.03 & 1.33 & 0.89 & 1.04 & 2.19 & 2.92 & 5.65 \\
\hline $\mathrm{Na}_{2} \mathrm{O}$ & 4.37 & 5.21 & 3.74 & 3.78 & 2.60 & 3.42 & 4.66 & 4.14 & 3.81 \\
\hline $\mathrm{K}_{2} \mathrm{O}$ & 5.17 & 5.21 & 5.01 & 5.18 & 6.11 & 5.12 & 6.86 & 6.23 & 3.92 \\
\hline $\mathrm{P}_{2} \mathrm{O}_{5}$ & 0.19 & 0.09 & 0.05 & 0.10 & 0.11 & 0.04 & 0.47 & 0.54 & 0.59 \\
\hline LOI & 0.43 & 0.21 & 0.76 & 0.36 & 0.47 & 0.28 & 0.22 & 0.45 & 0.50 \\
\hline Sum & 100.01 & 100.37 & 100.95 & 98.78 & 98.45 & 99.63 & 99.98 & 99.86 & 99.20 \\
\hline $\mathrm{Na}_{2} \mathrm{O}+\mathrm{K}_{2} \mathrm{O}$ & 9.54 & 10.42 & 8.75 & 8.96 & 8.71 & 8.54 & 11.52 & 10.37 & 7.73 \\
\hline $\mathrm{Na}_{2} \mathrm{O} / \mathrm{K}_{2} \mathrm{O}$ & 0.85 & 1.00 & 0.75 & 0.73 & 0.43 & 0.67 & 0.68 & 0.66 & 0.97 \\
\hline $\mathrm{A} / \mathrm{CNK}$ & 1.29 & 1.30 & 1.40 & 1.41 & 1.45 & 1.39 & 1.16 & 1.06 & 1.31 \\
\hline $\mathrm{A} / \mathrm{NK}$ & 1.66 & 1.57 & 1.56 & 1.62 & 1.60 & 1.56 & 1.38 & 1.36 & 2.27 \\
\hline $\mathrm{FeOt}$ & 3.70 & 2.51 & 1.80 & 1.23 & 1.38 & 1.72 & 3.95 & 4.93 & 6.73 \\
\hline Cs & 2.40 & 2.80 & 4.30 & 6.00 & 5.00 & 3.30 & 7.00 & 8.50 & 4.60 \\
\hline $\mathrm{Rb}$ & 124.30 & 136.50 & 280.40 & 361.30 & 250.30 & 257.60 & 281.30 & 263.60 & 104.60 \\
\hline $\mathrm{Ba}$ & 2605.00 & 2407.00 & 925.00 & 282.00 & 556.00 & 290.00 & 3000.00 & 2599.00 & 2360.00 \\
\hline $\mathrm{Sr}$ & 916.00 & 849.10 & 187.20 & 75.10 & 100.10 & 115.10 & 1248.50 & 1119.20 & 899.90 \\
\hline $\mathrm{Pb}$ & 13.20 & 14.70 & 8.70 & 13.80 & 4.70 & 6.00 & 45.20 & 58.10 & 4.60 \\
\hline Th & 13.80 & 9.00 & 42.90 & 39.30 & 25.80 & 42.00 & 14.30 & 18.20 & 4.40 \\
\hline $\mathrm{U}$ & 1.40 & 2.00 & 2.20 & 10.00 & 2.40 & 6.50 & 3.10 & 4.40 & 2.70 \\
\hline $\mathrm{Zr}$ & 221.40 & 198.60 & 201.60 & 95.20 & 97.70 & 93.90 & 764.10 & 685.00 & 439.70 \\
\hline
\end{tabular}




\section{Continued}

\begin{tabular}{|c|c|c|c|c|c|c|c|c|c|}
\hline $\mathrm{Hf}$ & 5.50 & 5.40 & 5.50 & 3.70 & 3.10 & 3.10 & 16.40 & 15.30 & 9.60 \\
\hline $\mathrm{Ta}$ & 1.00 & 0.50 & 1.40 & 4.30 & 0.30 & 1.30 & 1.80 & 2.10 & 0.50 \\
\hline $\mathrm{Y}$ & 22.00 & 14.20 & 10.00 & 39.70 & 4.70 & 10.70 & 15.80 & 21.00 & 18.00 \\
\hline $\mathrm{Nb}$ & 13.40 & 9.20 & 16.10 & 27.00 & 6.30 & 16.70 & 34.80 & 41.80 & 9.00 \\
\hline Sc & 7.00 & 5.00 & 3.00 & 4.00 & 2.00 & 3.00 & 6.00 & 9.00 & 8.00 \\
\hline $\mathrm{Ni}$ & 21.00 & 20.00 & 20.00 & 20.00 & 20.00 & 20.00 & 26.00 & 51.00 & 20.00 \\
\hline Co & 8.40 & 4.90 & 2.50 & 1.50 & 1.50 & 1.50 & 11.30 & 16.80 & 17.80 \\
\hline $\mathrm{V}$ & 59.00 & 45.00 & 19.00 & 8.00 & 8.00 & 8.00 & 88.00 & 95.00 & 97.00 \\
\hline W & 4.50 & 0.5 & 0.5 & 2.90 & 0.80 & 0.5 & 0.70 & 1.30 & 0.5 \\
\hline $\mathrm{Ga}$ & 16.70 & 15.90 & 21.50 & 20.70 & 21.70 & 16.20 & 20.90 & 18.80 & 20.60 \\
\hline $\mathrm{Zn}$ & 25.00 & 15.00 & 62.00 & 25.00 & 55.00 & 32.00 & 25.00 & 39.00 & 68.00 \\
\hline $\mathrm{Cu}$ & 12.40 & 4.40 & 4.10 & 2.00 & 1.30 & 2.50 & 84.60 & 72.10 & 12.00 \\
\hline $\mathrm{La}$ & 83.70 & 31.30 & 81.60 & 33.50 & 40.30 & 25.90 & 71.30 & 87.30 & 22.00 \\
\hline $\mathrm{Ce}$ & 104.90 & 51.30 & 148.60 & 66.90 & 77.00 & 49.90 & 126.60 & 155.90 & 50.60 \\
\hline $\mathrm{Pr}$ & 9.86 & 5.39 & 15.34 & 7.44 & 7.80 & 5.51 & 13.50 & 16.96 & 6.77 \\
\hline $\mathrm{Nd}$ & 32.90 & 19.20 & 49.50 & 25.90 & 27.80 & 19.10 & 48.20 & 60.50 & 28.90 \\
\hline $\mathrm{Sm}$ & 5.64 & 3.13 & 7.24 & 5.74 & 5.15 & 4.44 & 7.90 & 10.01 & 5.76 \\
\hline $\mathrm{Eu}$ & 1.36 & 0.89 & 0.94 & 0.48 & 0.61 & 0.42 & 2.13 & 2.51 & 1.75 \\
\hline Gd & 4.81 & 2.86 & 4.19 & 5.35 & 3.51 & 3.60 & 5.52 & 7.40 & 4.98 \\
\hline $\mathrm{Tb}$ & 0.69 & 0.43 & 0.48 & 0.98 & 0.34 & 0.50 & 0.68 & 0.88 & 0.68 \\
\hline Dy & 3.92 & 2.42 & 2.09 & 5.93 & 1.30 & 2.43 & 3.06 & 4.06 & 3.67 \\
\hline Ho & 0.75 & 0.50 & 0.31 & 1.29 & 0.15 & 0.41 & 0.50 & 0.69 & 0.68 \\
\hline Er & 2.18 & 1.51 & 0.94 & 4.19 & 0.34 & 1.09 & 1.38 & 1.99 & 1.87 \\
\hline $\mathrm{Tm}$ & 0.34 & 0.23 & 0.13 & 0.68 & 0.05 & 0.15 & 0.21 & 0.27 & 0.26 \\
\hline $\mathrm{Yb}$ & 2.24 & 1.49 & 0.80 & 4.68 & 0.32 & 1.00 & 1.39 & 1.75 & 1.62 \\
\hline $\mathrm{Lu}$ & 0.35 & 0.24 & 0.12 & 0.71 & 0.05 & 0.18 & 0.21 & 0.26 & 0.26 \\
\hline $\mathrm{Ti}$ & 3039.09 & 2026.06 & 1668.52 & 655.49 & 1191.80 & 536.31 & 4707.61 & 5243.92 & 6912.44 \\
\hline $\mathrm{Eu} / \mathrm{Eu}^{*}$ & 0.80 & 0.91 & 0.52 & 0.26 & 0.44 & 0.32 & 0.98 & 0.89 & 1.00 \\
\hline$(\mathrm{La} / \mathrm{Sm}) \mathrm{N}$ & 8.64 & 5.82 & 6.56 & 3.40 & 4.56 & 3.40 & 5.26 & 5.08 & 2.22 \\
\hline$(\mathrm{La} / \mathrm{Yb}) \mathrm{N}$ & 25.38 & 14.27 & 69.29 & 4.86 & 85.55 & 17.59 & 34.85 & 33.89 & 9.23 \\
\hline$(\mathrm{Gd} / \mathrm{Lu}) \mathrm{N}$ & 1.70 & 1.47 & 4.32 & 0.93 & 8.68 & 2.47 & 3.25 & 3.52 & 2.37 \\
\hline
\end{tabular}

\subsubsection{Distribution of Major Elements}

Granitoids have variable major element contents: $55.92 \%$ to $74.75 \% \mathrm{SiO}_{2}, 0.09 \%$ to $1.16 \%$ for $\mathrm{TiO}_{2}, 13.36 \%$ to $17.9 \% \mathrm{Al}_{2} \mathrm{O}_{3}, 1.36 \%$ to $7.47 \% \mathrm{Fe}_{2} \mathrm{O}_{3}, 0.01$ to 0.09 $\mathrm{MnO}, 0.98$ to 5.2 for $\mathrm{CaO}, 2.81$ to 4.43 of $\mathrm{Na}_{2} \mathrm{O}, 3.96$ to 6.93 for $\mathrm{K}_{2} \mathrm{O}, 0.03$ to 0.64 of $\mathrm{P}_{2} \mathrm{O}_{5}$. The sum of the alkalis $\left(\mathrm{Na}_{2} \mathrm{O}+\mathrm{K}_{2} \mathrm{O}\right)$ is between $7.73 \%$ and $11.52 \%$ and 
the $\mathrm{Na}_{2} \mathrm{O} / \mathrm{K}_{2} \mathrm{O}$ ratio varies from $0.43 \%$ to $1.0 \%$. The diagram of Cox et al. [20], adapted to plutonic rocks by Wilson [21] allows discriminating the granitoids of the Baïbokoum-Touboro-Ngaoundaye region (Figure 5(a)) for granites, syenites and monzonite (syeno-diorite). In the $\mathrm{K}_{2} \mathrm{O}$ versus $\mathrm{SiO}_{2}$ diagram of [22] (Figure 5(b)), the majority of samples fall into the shoshonitic series. Two (02) biotite and muscovite granites are observed in the field of the hyperpotassium calc-alkaline series. Harker diagrams [23] are used to see the evolution of major rock elements in the Baibokoum-Touboro-Ngaoundaye region (Figure 6). There is a decrease in the content of $\mathrm{TiO}_{2}, \mathrm{MgO}, \mathrm{CaO}, \mathrm{Fe}_{2} \mathrm{O}_{3}, \mathrm{MnO}$ and $\mathrm{P}_{2} \mathrm{O}_{5}$ with increasing $\mathrm{SiO}_{2}$ content. This illustrates a more or less clear negative correlation between these oxides and $\mathrm{SiO}_{2}$. The $\mathrm{Na}_{2} \mathrm{O}, \mathrm{Al}_{2} \mathrm{O}_{3}$ versus $\mathrm{SiO}_{2}$ diagrams show a dispersion of the representative points of the samples analyzed.

\subsubsection{Trace Elements Distribution}

The rare earth spectra normalized to chondrites according to the values of [24] (Figure 7(a)), underline an enrichment in light rare earths element (LREE) compared to heavy rare earths element (HREE). Rare earth spectra of amphibole granite show high fractionation $(\mathrm{La} / \mathrm{Yb}) \mathrm{N}=14.27$ to 25.38 and heavy rare earth profile segments almost flat $[(\mathrm{Gd} / \mathrm{Lu}) \mathrm{N}=1.47$ to 1.70$]$. The negative $\mathrm{Eu}$ anomaly is very small, $\mathrm{Eu} / \mathrm{Eu}^{*}=0.80-0.91$. The earth spectra of the two-mica granite show a slightly variable light rare earth fractionation $((\mathrm{La} / \mathrm{Sm}) \mathrm{N}=3.39$ to 6.56) unlike the heavy earths which show a fractionation to the other. [ $(\mathrm{Gd} / \mathrm{Lu}) \mathrm{N}$ $=0.93-8.68]$. We note the presence of a negative anomaly in europium $\left(\mathrm{Eu} / \mathrm{Eu}^{*}=\right.$ $0.26-0.52)$. The syenite samples have parallel profiles, with a high fractionation $[(\mathrm{La} / \mathrm{Yb}) \mathrm{N}=33.89$ to 34.85$]$ and an absence of an anomaly in $\mathrm{Eu}\left(\mathrm{Eu} / \mathrm{Eu}^{*}=0.89\right.$
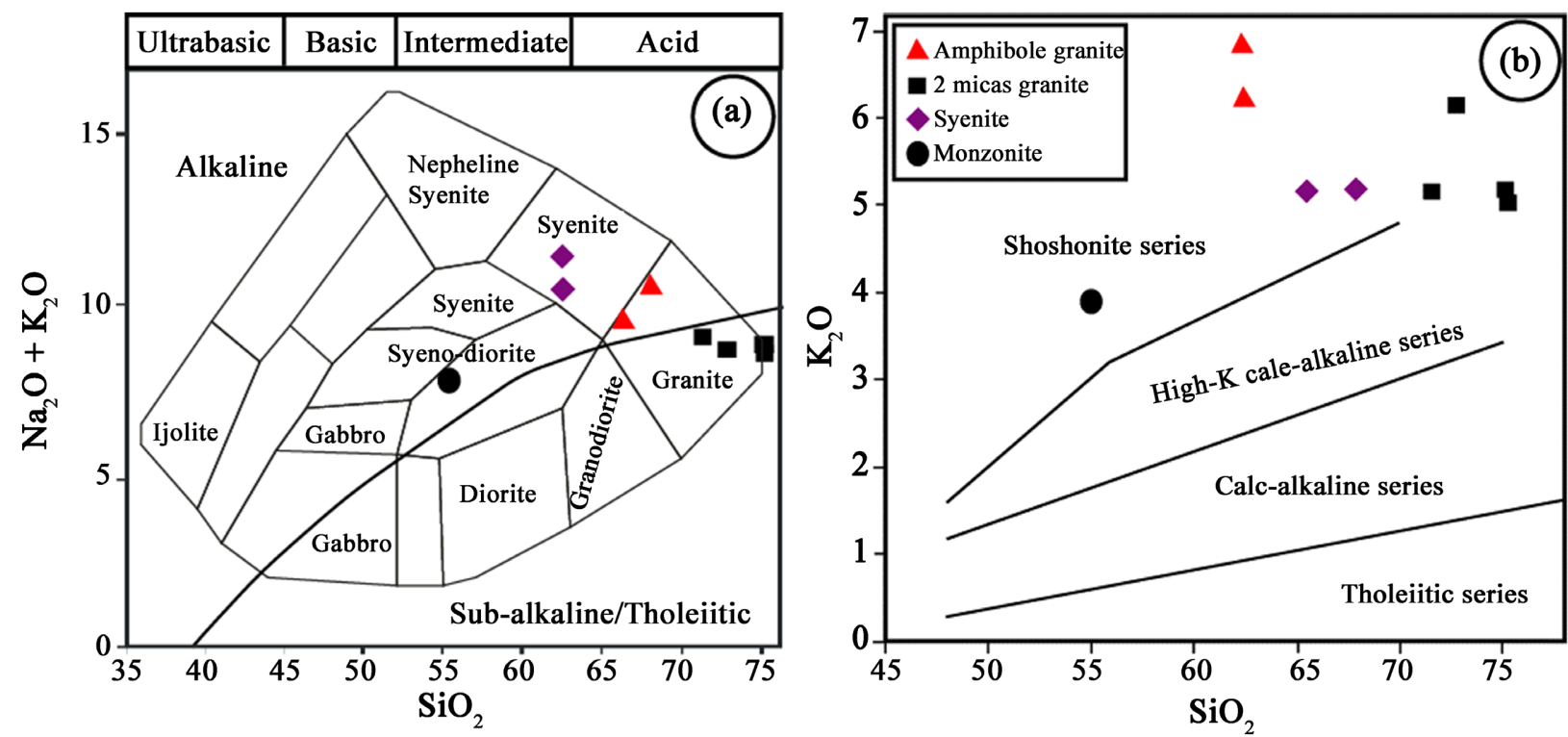

Figure 5. (a) Classification of plutonic rocks of the Baibokoum-Touboro-Ngaoundaye region in the diagram of Cox et al. [20], adapted to plutonic rocks by Wilson [21]. The red line curve limits the fields of alkaline and sub-alkaline rocks according to Irvine and Barragar [25]. (b) Diagram of $\mathrm{K}_{2} \mathrm{O}$ as a function of $\mathrm{SiO}_{2}$ according to Le Maitre et al. [22] showing a shoshonitic, calc-alkaline potassium to hyper-potassium affinity of granitoids from the Baibokoum-Touboro-Ngaoundaye region. 

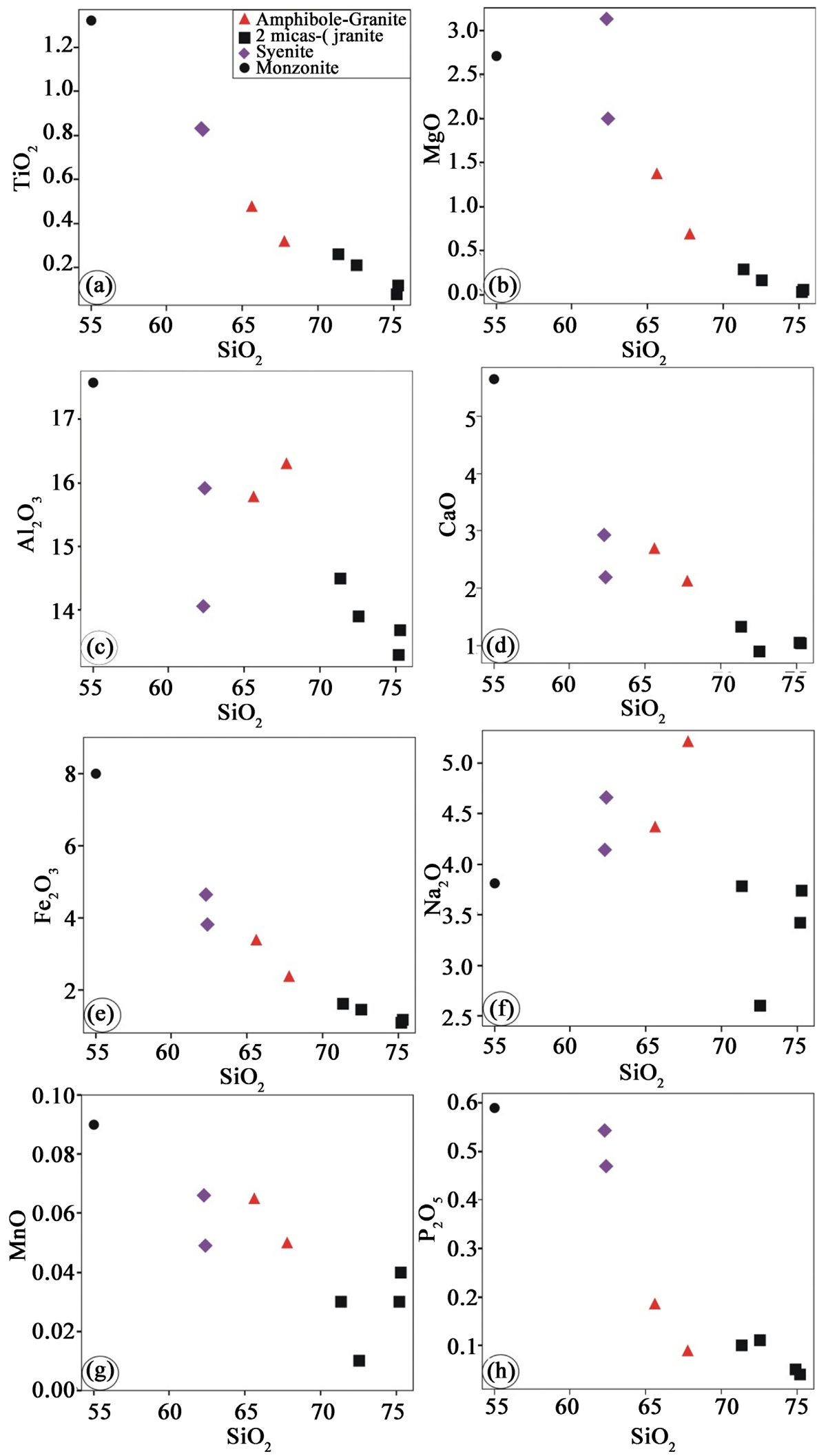

Figure 6. Variation diagrams of major elements as a function of $\mathrm{SiO}_{2}\left((\mathrm{a}) \mathrm{TiO}_{2}-\mathrm{SiO}_{2}\right.$; (b) $\mathrm{Al}_{2} \mathrm{O}_{3}-\mathrm{SiO}_{2}$; (c) $\mathrm{Fe}_{2} \mathrm{O}_{3}-\mathrm{SiO}_{2} \mathrm{Al}_{2} \mathrm{O}_{3}-\mathrm{SiO}_{2}$; (d) $\mathrm{MnO}-\mathrm{SiO}_{2}$; (e) $\mathrm{MgO}-\mathrm{SiO}_{2}$; (f) $\mathrm{CaO}-\mathrm{SiO}_{2}$; (g) $\mathrm{Na}_{2} \mathrm{O}-\mathrm{SiO}_{2} ;(\mathrm{h}) \mathrm{P}_{2} \mathrm{O}_{5}-\mathrm{SiO}_{2}$ ). 

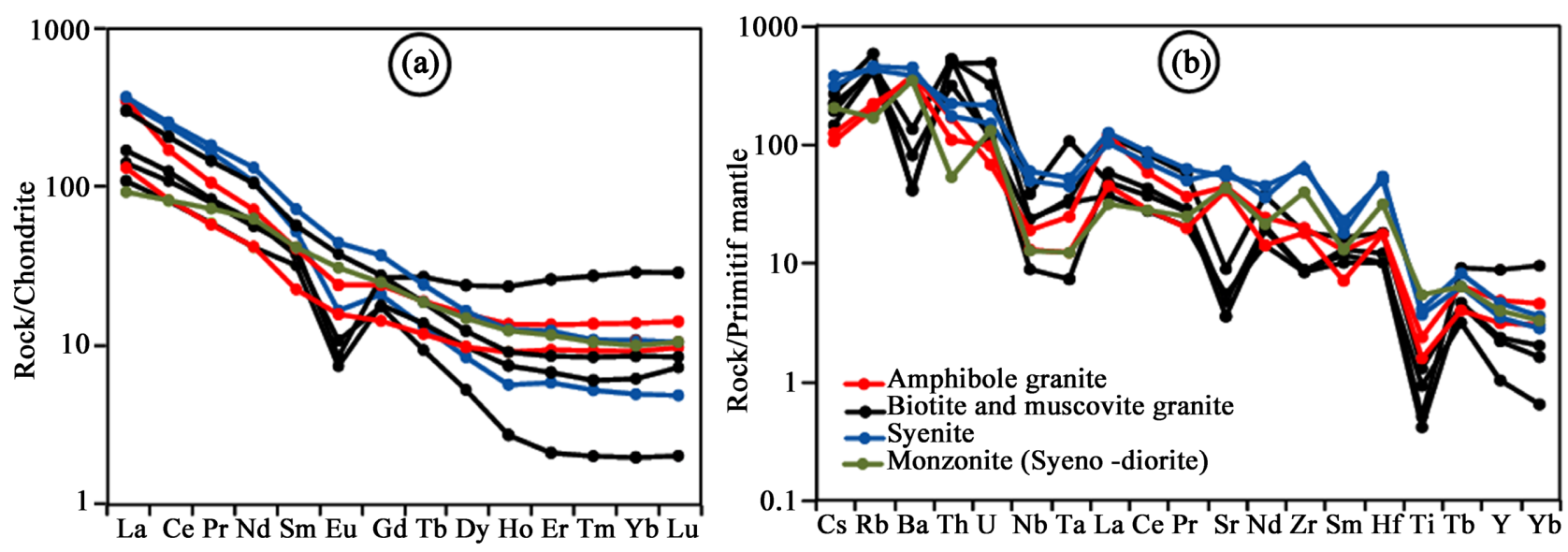

Figure 7. (a) Rare earth spectra of granotoïds rocks from the Baïbokoum-Touboro-Ngaoundaye area normalized to chondrites according to the values of Mc Donough [25]. (b) Multielement spectra of granitoïds rocks of the Baibokoum-Touboro-Ngaoundaye area normalized to the primitive mantle of Mc Donough [25].

to 0.98$)$. The monzonite (syeno-diorite) shows strong fractionation $[(\mathrm{La} / \mathrm{Yb}) \mathrm{N}=$ 9.23] and the almost horizontal heavy rare earth profile [ $(\mathrm{Gd} / \mathrm{Lu}) \mathrm{N}=2.37]$. We also note an absence of an anomaly in $\mathrm{Eu}\left(\mathrm{Eu} / \mathrm{Eu}^{*}=1.00\right)$. The phased array spectra of rocks from the Baïbokoum-Touboro-Ngaoundaye region normalized to the primitive mantle (Figure 7(b)) show an enrichment in lithophile elements (LILE) compared to elements with high ionic potential (HSFS). We note for all these rocks the presence of a negative anomaly in Nb-Ta and Ti. The biotite and muscovite granite and amphibole biotite have a negative $\mathrm{Ba}$ and $\mathrm{Sr}$ anomaly. The monzonite presents positive $\mathrm{Ba}$ anomaly. Syenite and monzonite (syeno-diorite) show positive $\mathrm{Zr}$ and $\mathrm{Hf}$ anomaly.

\section{Discussion}

\subsection{Petrogenic Implication}

The nomenclature of plutonic rocks in the Baibokoum-Touboro-Ngaoundaye area places the samples in the fields of granitoids made up of granite, monzonite (syeno-diorite) and syenite (see Figure 5(a)). These granitoids belong to the calc-alkaline series, strongly potassic to shoshonitic (see Figure 5(b)). The distribution of the major elements in the Harker diagram [23] (see Figure 6) shows a linear correlation of rock formations in the Baïbokoum-Touboro-Ngaoundaye region. The linearly negatively correlated arrangement between $\mathrm{SiO}_{2}$ and the oxides $\mathrm{Fe}_{2} \mathrm{O}_{3}, \mathrm{Al}_{2} \mathrm{O}_{3}, \mathrm{MgO}, \mathrm{CaO}, \mathrm{MnO}, \mathrm{TiO}_{2}$ and $\mathrm{P}_{2} \mathrm{O}_{5}$, explains the emergence of the processes of fractional crystallization [26] [27]. This approximately linear arrangement would indicate, according to several works by authors [26] [28] [29] [30] [31] [32] the intervention of magmatic mixing between a basic magma and an acid magma as well as fractional crystallization process. The high contents of $\mathrm{Al}_{2} \mathrm{O}_{3} \mathrm{wt} \%$ and $\mathrm{K}_{2} \mathrm{O}$ wt $\%$, would mainly confirm the abundance of muscovite and microcline in these plutonic rocks (see. Figure 4(d)). The decreases in $\mathrm{Fe}_{2} \mathrm{O}_{3}, \mathrm{Al}_{2} \mathrm{O}_{3}$ and $\mathrm{MnO}$ reflect the fractional crystallization of the 
first silicate minerals of ferromagnesians and that of titanium oxides [30]. The presence of hydrated minerals such as amphibole and biotite in the plutonic rocks of the study area suggests on one hand that the source is melting under hydrated conditions [33] and on the other hand, mantellic origin of the source magma [34].

The enrichment in light rare earths (LREE) (cf. Figure 7(a)) denotes the fractionation of accessory minerals such as apatite, while the depletion of heavy rare earth elements (HREE) is attributed to the fractionation of zircon [35] [36]. The negative anomaly in Eu observed for the majority of granitoïds rocks in the Baïbokoum-Touboro-Ngaoundaye area reflects the fractionation of plagioclase during the evolution of the parent magma [37]. The absence of a negative Eu anomaly in the monzonite and syenite (cf. Figure 7(a)) despite the presence of plagioclase in these rocks; is explained by the fact that Eu may not have been introduced into the plagioclase and may also reflect strong oxydation conditions where all of the $\mathrm{Eu}$ is in the form of $\mathrm{Eu}^{3+}$ or limited fractionation of the plagioclase in the source [38]. The same observation was made in the granitoïds of Mbip and Doua-Kalaldi-Badzer respectively by [14] and [39]. The abundance of ferromagnesian minerals in these rocks, such as amphibole, suggests that the melting that occurred has a magmatic source of mantle origin [34].

\subsection{Tectonic Context}

The $\mathrm{Nb}$ versus $\mathrm{Yb}$ discriminant diagram of [40] shows that most of the plutonic rock samples from the Baïbokoum-Touboro-Ngaoundaye area are found in the domain of volcanic arc granitoids and two samples of amphibole granite fall into the intraplate anorogenic domain (WPG) (Figure 8(a)). As for the discriminating diagram $\mathrm{Rb}$ as a function of $(\mathrm{Y}+\mathrm{Rb})$ of [40], the majority of the samples fall in the field of syn-collisional granitoids (Syn-COLG) and three samples (two syenites and one monzonite) in the field of intraplate granitoids (Figure 8(b)). The triangular diagram of [41] (Figure 8(c)) shows that almost the entire samples plot within the domain of volcanic arc granitoids. With the exception of a single sample of two-mica granite which falls in the intraplate anorogenic domain. The potassic to highly potassic and shoshonitic calc-alkaline character of the rocks studied (cf. Figure 5(b)) and the negative anomaly in $\mathrm{Ta}-\mathrm{Nb}$ and $\mathrm{Ti}$ are compatible with a geodynamic environment of continental collision leading to subduction [42]. The characteristic of the negative Ta-Nb anomaly of subduction zone magmas [43] is assured during reflow from the subducted lithosphere [44] [45] and represents an important inherited imprint. In general, strongly potassic calc-alkaline granitoids show a continent-continent collision or volcanic arc tectonic environment [35] [46] [47].

\subsection{Comparison of Granitoids from the Study Area with Granitoids from the Adamaoua-Yadé Domain}

The multi-element synthesis spectra of Baïbokoum-Touboro-Ngaoundaye 

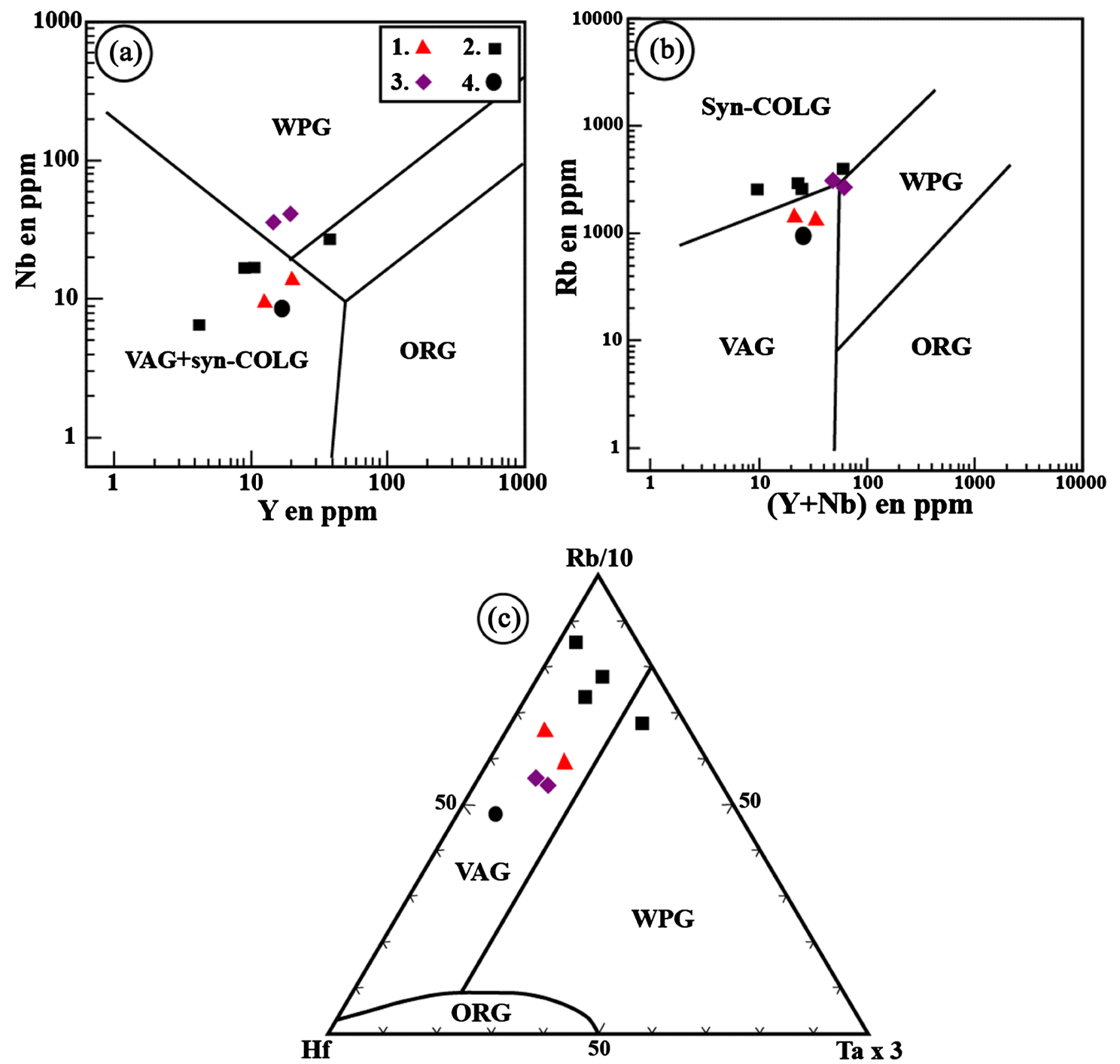

VAG: volcanic arc granitoids; WPG: intraplate granitoids; ORG: oceanic ripple granitoids; Syn-COLG: Syn-collisional granitoids 1 . Biotite and muscovite granite; 2. Syenite; 3 . Amphibole granite; 4 . Monzonite.

Figure 8. Position of rocks samples of Baibokoum-Touboro-Ngaoundaye area in the discrimination diagram of the geotectonic setting of $\mathrm{Nb}$ as a function of $\mathrm{Y}(\mathrm{a})$ and $\mathrm{Rb}$ as a function of $(\mathrm{Y}+\mathrm{Nb})(\mathrm{b})$ by [40]; (c) Discrimination diagram of the geotectonic context after [41].

granitoids with the primitive mantle [25] were carried out. The comparison between the granitoids of the study area and those of the region of Ngaoundere [48], Bafoussam [49] and Doua-Kalaldi-Badzer [39] is shown in Figure 9. On this diagram, the profiles of the Baïbokoum-Touboro-Ngaoundaye granitoids observed, present a parallelism with the fields defined by the granitoids of Ngaoundéré, Bafoussam and Doua-Kalaldi-Badzer. All the spectra of these granitoids show negative anomalies in $\mathrm{Ta}-\mathrm{Nb}$ and $\mathrm{Ti}$. There is a difference between these granitoids for $\mathrm{Ba}$ and $\mathrm{Sr}$ elements. Monzonite show negative anamaly in $\mathrm{Ba}$. The difference is also observed for positive anomalies in $\mathrm{Sr}$ (amphibole granite, syenite and monzonite) and the same positive anomalies for the Doua-KalaldiBadzer granitoids. Biotite and muscovite granite present positive anomaly in Th 


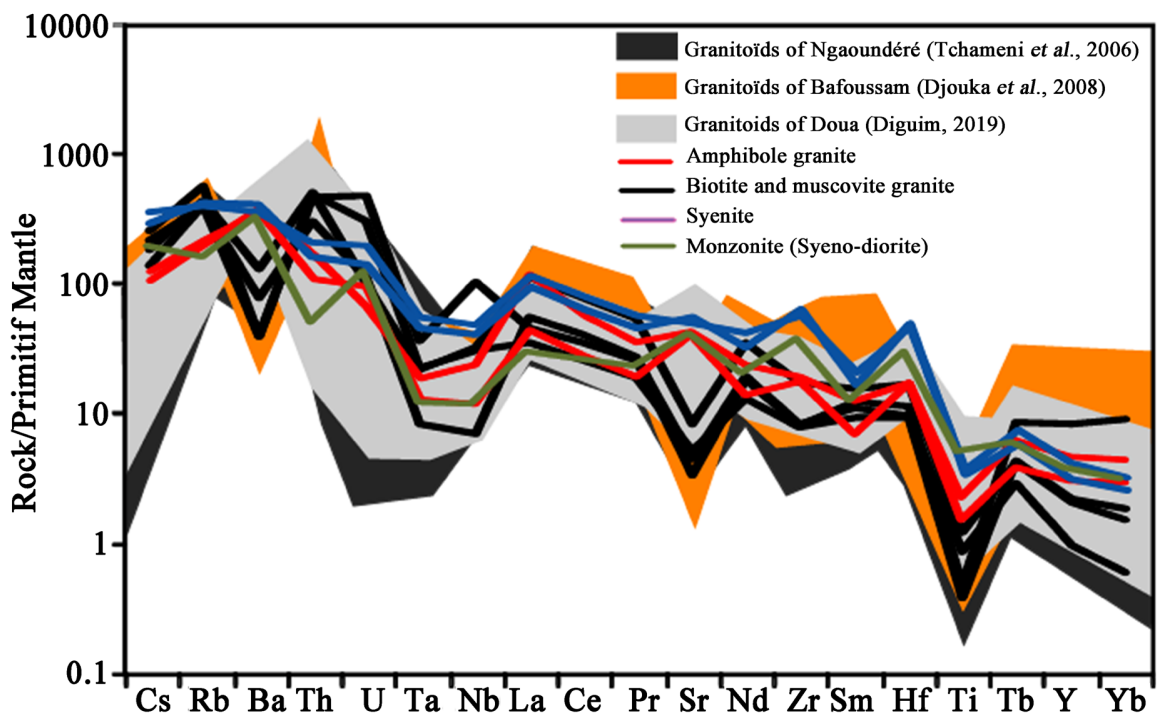

Figure 9. Synthesis multi-element spectra of granitoids from the Baïbokoum-TouboroNgaoundaye area.

similar to the granitoids of Bafoussam and Meiganga. The rest of the granitoids of the study area do not show a positive anomaly in Th. The various observations made allow us to deduce that the granitoids of the study area integrate the granitoids field of the Adamawa-Yade domain of the Pan-African fold belt of Central Africa.

\section{Conclusion}

Plutonic rocks of the study area consist of amphibole granite, two-mica granite, monzonite and syenite. Granite, monzonite and syenites have a granular porphyroid texture. The primary paragenesis consists of the Opx + Cpx + Amp + Bt $+\mathrm{Pl}+\mathrm{Ort}+\mathrm{Mic}+\mathrm{Qtz}+\mathrm{Ap}+\mathrm{Sph}+\mathrm{Zr}$ assembly and the secondary paragenesis consists of $\mathrm{Chl}+\mathrm{Op}$. These rocks are shoshonitic to calc-alkaline strongly potassic. The placement of these plutonic rocks is known by the process of fractional crystallization. The granitoids of Baïbokoum-Touboro-Ngaoundaye show an enrichment in light rare earth elements (LREE) compared to heavy rare earth elements (HREE), an enrichment in LILE (Large Ion Lithophile) compared to HSFE (High Field strength Element). The majority of these rocks present a negative anomaly in $\mathrm{Eu}$. They are rocks of crustal origin (negative anomaly in $\mathrm{Ta}-\mathrm{Nb}, \mathrm{Sr}$ and $\mathrm{Ti}$ ) with the addition of mantle material. Plutonic rocks are placed in a volcanic arc to syn-collisional environment and an intraplate environment. Petrography and Geochemistry of Baibokoum-Touboro-Ngaoundaye Granitoids thus indicate compressional geotectonic setting implicating volcanic arc and continental plate.

\section{Acknowledgements}

Thanks go to editor, and anonymous reviewers, for their critical comments on the manuscript. 


\section{Conflicts of Interest}

The authors declare no conflicts of interest regarding the publication of this paper.

\section{References}

[1] Njanko, T., Nedelec, A. and Affaton, P. (2006) Synkinematic High-K Calc-Alkaline Plutons Associated with the Pan-African Central Cameroon Shear Zone (W-Tibati Area): Petrology and Geodynamic Significance. Journal of Africa Earth Sciences, 44, 494-510. https://doi.org/10.1016/j.jafrearsci.2005.11.016

[2] Njanfang, E., Ngako, V., Moreau, C., Affaton, P. and Diof, H. (2008) Restraining Bends in High Temperature Shear Zone: The "Central Cameroon Shear Zone", Central Africa. Journal of Africa Earth Sciences, 52, 9-20. https://doi.org/10.1016/j.jafrearsci.2008.03.002

[3] Toteu, S.F., Penaye, J. and Poudjom, D.Y. (2004) Geodynamic Evolution of the Pan-African Belt in Central Africa with Special Reference to Cameroon. Canadian Jounal of Earth Sciences, 41, 73-85. https://doi.org/10.1139/e03-079

[4] Ganwa, A.A. (2005) Les granitoïdes de Méiganga: Etude pétrographique, géochimique, structurale et géochronologique. Leur place dans la chaîne panafricaine. Thèse d'État ès sciences naturelles, Université de Yaoundé I, Yaoundé, 162 p.

[5] Nzenti, J.P., Badibanga, K., Gerhard, W. and Ruananza, T.L. (2006) Synkinematic Emplacement of Granitoids in a Pan-African Shear Zone in Central Cameroon. Journal of African Earth Sciences, 45, 75-76. https://doi.org/10.1016/j.jafrearsci.2006.01.005

[6] Jérémine, E. (1951) Sur une perthite syénite de Baïbokoum et une perthite-granulite de Passi (territoire sud du Tchad) B.S.G.Fr. (6), t.1, fasc. 1,2,3.

[7] Gerard, G. (1954) Bossangoa-ouest: Rapport de fin de mission 1953-Dir. MINES Géol. AEF, Brazzaville.

[8] Mbaitoudji, M.M. (1984) Lois de répartition, hypothèse de pronostics et méthodologie de la recherche des gisements de minéraux utiles solides dans le territoire de la République du Tchad. Publication CIFEG, Paris, 14 p.

[9] Kasser, M. (1995) Evolution précambrienne de la région de Mayo-Kebbi (Tchad) Un segment de la chaine panafricaine. Thèse de Doctorat, Muséum National, Histoire Naturelle, Paris, $217 \mathrm{p}$.

[10] Naïmou, S., Ganwa, A.A., Urs, K., Amadou, D.K. and Ekodeck, G.E. (2014) Petrography and Geochemistry of Precambrian Basement Straddling the Cameroon-Chad Border: The Touboro-Baibokoum Area. International Journal of Geosciences, 5, 418-431. https://doi.org/10.4236/ijg.2014.54040

[11] Naïmou, S. (2020) Etudes géomorphologique, pétrographique, structurale et géochimique de la région Baïbokoum-Touboro-Ngaoundaye aux confins Tchad-Cameroun-Centrafrique. Thèse de doctorat $\mathrm{Ph} / \mathrm{D}$, Université de Ngaoundéré, Ngaoundéré, 208 p.

[12] Poidevin, J.L. (1991) Les ceintures de roches vertes de la République Centrafricaine. Contribution à la connaissance du Précambrien du nord du craton du Congo. Doctorat d'Etat, Université Blaise Pascal, Clermont-Ferrand (France).

[13] Bouyo, H.M., Penaye, J., Barbey, P., Toteu, S.F. and Wandji, P. (2013) Petrology of High-Pressure Granulite Facies Metapelites and Metabasites from Tcholliré and Banyo Regions: Geodynamic Implication for the Central African Fold Belt (CAFB) 
of North-Central Cameroon. Precambrian Research, 224, 412-433. https://doi.org/10.1016/j.precamres.2012.09.025

[14] Nomo, N.E. (2017) Signification géodynamique de la faille de Tcholliré-Banyo: Apport de la pétrologie, de l'analyse structurale, de la géochimie et de la géochronologie des roches de la région de Tcholliré (Nord Cameroun). Thèse de Doctorat $\mathrm{Ph} / \mathrm{D}$, Université de Ngaoundéré, Ngaoundéré, 233 p.

[15] Saha, F.A.N. (2018) Croissance et remobilisation crustale au Néoprotérozoïque: Magmatisme, métamorphisme et déformation le long de la zone de cisaillement de Tcholliré-Banyo (région de Mbé-Sassa-Mbersi). Thèse de Doctorat $\mathrm{Ph} / \mathrm{D}$, Université de Ngaoundéré, Ngaoundéré, 352 p.

[16] Bessoles, B. and Trompette, R. (1980) Géologie de l'Afrique. La chaîne panafricaine zone mobile de l'Afrique (partie Sud) et zone mobile Soudanaise. Memoire du BRGM, Paris, 375 p.

[17] Abdelsalam, M.G., Liégeois, J.P. and Stern, R.J. (2002) The Saharan Metacraton. Journal of African Earth Sciences, 34, 119-136. https://doi.org/10.1016/S0899-5362(02)00013-1

[18] Dorbath, L., Dorbath, C., Stuart, G.W. and Fairhead, J.D. (1984) Structure de la croûte sous le plateau de l'Adamaoua (Cameroun). Compte Rendu de I Academie des Sciences de Paris, 298, 539-542.

[19] Kusnir, I. (1993) Géologie, ressources minérales et ressources en eau du Tchad-Trav. Doc. SC. Tchad, connait. Tchad, 1, CNAR.

[20] Cox, K.G., Bell, J.D. and Pankust, R.J. (1979) The Interpretation of Igneous Rocks. George Allen \& Unwin, Crows Nest. https://doi.org/10.1007/978-94-017-3373-1

[21] Wilson, M. (1989) Igneous Petrogenesis. Unwin Hyman, London, 466 p. https://doi.org/10.1007/978-1-4020-6788-4

[22] Le Maitre, R.W., Bateman, P., Dudek, A., Keller, J., Lameyre, M., Le Bas, M.J., Sabine, P.A., Schmid, R., Sorensen, H., Streckeisen, A., Woolley, A.R. and Zanettin, B. (1989) A Classification of Igneous Rocks and Glossary of Terms. Recommendations of the IUGS Commission on the Systematics of Igneous Rocks. Blackwell, Oxford, $193 \mathrm{p}$.

[23] Harker (1909) The Natural History of Igneous Rocks. Methuen, London.

[24] Mc Donough, W.F. and Sun, S.S. (1995) The Composition of the Earth. Chemical Geology, 120, 223-253. https://doi.org/10.1016/0009-2541(94)00140-4

[25] Irvine, T.N. and Barragar, W.R.A. (1971) A Guide to the Chemical Classification of the Common Volcanic Rocks. Canadian Journal of Earth Sciences, 8, 523-548. https://doi.org/10.1139/e71-055

[26] Clemens, J.D. and Wall, V.J. (1981) Origin and Crystallization of Some Peraluminous (S-Type) Granitic Magmas. Canadian Mineralogist, 19, 111-131.

[27] Liankun, S. and Kuirong, Y. (1989) A Two-Stage Crust-Mantel Interaction Model for Mafic Microgranular Enclaves in the Daning Granodiorite Pluton, Guangxi, China. In: Didier, J. and Barbarin, B., Eds., Enclaves and Granite Petrology, Developments in Petrology, Vol. 13, Elsevier, Amsterdam, 95-110.

[28] Kouchi, A. and Sunagawa, I. (1985) A Model for Mixing Basaltic and Dacitic Magmas as Deduced from Experimental Data. Contributions to Mineralogy and Petrology, 89, 17-23. https://doi.org/10.1007/BF01177586

[29] Haïmeur, J., El Amrani El Hassani, I.-E. and Chabane, A. (2004) Pétrologie et géochimie des granitoïdes calco-alcalins de Zaër (Maroc central): Modèle pétrogénétique. Bulletin de l'Institut Scientifique, Rabat, section Sciences de la Terre, $\mathrm{n}^{\circ} 2004$, 
$\mathrm{n}^{\circ} 26,27-48$.

[30] Zorpi, M.J., Coulon, C., Orsini, J.B. and Cocirta, C. (1989) Magma Mingling, Zoning and Emplacement in Calc-Alkaline Granitoid Plutons. Tectonophysics, 157, 315-329. https://doi.org/10.1016/0040-1951(89)90147-9

[31] Orsini, J.B., Cocirta, C. and Zorpi, M.J. (1991) Genesis of Mafic Microgrenular Enclaves Trough Differentiation of Basic Magmas, Mingling and Chemical Exchanges with Their Host Granitoïd Magma. In: Didier, J. and Babarin, B., Eds., Enclaves and Granite Petrology, Developments in Petrology, Vol. 13, Elsevier, Amsterdam, 445-463.

[32] Boukaoud, E.H. (2007) Etude pétrographique et géochimique des pegmatites de Sidi Mezghiche (Wilaya de Skikda, nord-est algérien). Mémoire de magistère, université Mentouri Constantine, $134 \mathrm{p}$.

[33] Class, C. and Goldstein, S.L. (1997) Plume-Lithosphere Interactions in the Ocean Basins: Constraints from the Source Mineralogy. Earth and Planetary Science Letters, 150, 245-260. https://doi.org/10.1016/S0012-821X(97)00089-7

[34] Peycru, P., Dupin, J.M., Fogelgesang, J.F., Van, D.R.C., Cariou, F., Perrier, C. and Augère, B. (2008) Géologie, Tout-En-Un. BCPST. Dunod, Paris, 641 p.

[35] Rollingson, H.R. (1993) Using Geochemical Data: Evaluation, Presentation, Interpretation. Pearson Education Limited, Essex, 352 p.

[36] Zaraisky, G., Aksyuk, A., Devyatova, V., Udoratina, O. and Chevychelov, V. (2009) The Zr/Hf Ratio as a Fractionation Indicator of Rare-Metal Granites. Petrology, 17, 25-45. https://doi.org/10.1134/S0869591109010020

[37] Zhu, D., Mo, X., Wang, L., Zhao, Z., Niu, Y., Zhou, C. and Yang, Y. (2009) Petrogenesis of Highly Fractionated I-Type Granites in the Zayu Area of Eastern Gangdese, Tibet: Constraints from Zircon U-Pb Geochronology, Geochemistry and Sr-Nd-Hf Isotopes. Science in China, Series D: Earth Sciences, 52, 1223-1239. https://doi.org/10.1007/s11430-009-0132-x

[38] Davidson, J.P., McMillan, N.J., Moorbath, S., Worner, G., Harmon, R.S. and Lopez-Escobar, L. (1990) The Nevados de Payachata Volcanic Region $\left(18^{\circ} \mathrm{S} / 69^{\circ} \mathrm{W}\right.$, N) II. Evidence for Widespread Crustal Involvement in Andean Magmatism. Contributions to Mineralogy and Petrology, 105, 412-432. https://doi.org/10.1007/BF00286829

[39] Amadou, D.K. (2019) Etude pétrologique et structurale de la region de Doua-Kalaldi-Badzer dans le domaine Adamaoua-Yadé de la chaine panafricaine (Adamoua-Cmeroun). Thèse de doctorat $\mathrm{Ph} / \mathrm{D}$, Université de Ngaoundéré, Ngaoundéré, $209 \mathrm{p}$.

[40] Pearce, J.A., Harris, N.B.W. and Tindle, A.G. (1984) Trace Element Discrimination Diagrams for the Tectonic Interpretation of Granitic Rocks. Journal of Petrology, 25, 956-983. https://doi.org/10.1093/petrology/25.4.956

[41] Harris, N.B.W., Pearce, J.A. and Tindle, A.G. (1986) Geochimical Characteristics of Collision-Zone Magmatism. In: Coward, M.P. and Reis, A.C., Eds., Collision Tectonics, Geological Society, London, Special Publications 19, 67-81. https://doi.org/10.1144/GSL.SP.1986.019.01.04

[42] Bouyo, M.H., Zhao, Y., Penaye, J., Zhang, S.H. and Njel, U.O. (2015) Neoproterozoic Subduction-Related Metavolcanic and Metasedimentary Rocks from the Rey Bouba Greenstone Belt of North-Central Cameroon in the Central African Fold Belt: New Insights into a Continental Arc Geodynamic Setting. Precambrian Research, 21, 40-53. https://doi.org/10.1016/j.precamres.2015.01.012

[43] Green, T.H. (1995) Signification of Nb/Ta as an Indicator of Geochemical Processes in the Crust-Mantle System. Chemical Geology, 120, 347-359. 
https://doi.org/10.1016/0009-2541(94)00145-X

[44] Liégeois, J.P., Navez, J., Hertogen, J. and Black, R. (1998) Contrasting Origin of Post-Collisional High-K Calc-Alkaline and Shoshonitic versus Alkaline and Peralkaline Granitoids. Lithos, 45, 1-28. https://doi.org/10.1016/S0024-4937(98)00023-1

[45] Morrisson, G.A., Larson, P.B. and Hooper, P.R. (2000) "Subduction Style" Magmatism in a Non-Subduction Setting: The Coville Igneous Complex, NE Washington State, USA. Journal of Petrology, 41, 43-67. https://doi.org/10.1093/petrology/41.1.43

[46] Black, R. and Liégeois, J.P. (1993) Cratons, Mobile Belts, Alkaline Rocks and Continental Lithospheric Mantle: The Pan-African Testimony. Journal of the Geological Society, 150, 89-98. https://doi.org/10.1144/gsigs.150.1.0088

[47] Barbarin, B. (1999) A Review of the Relationships between Granitoids Types, Their Origins and Tectonic Setting. Geological Journal, 25, 605-626. https://doi.org/10.1016/S0024-4937(98)00085-1

[48] Tchameni, R., Pouclet, A., Penaye, J., Ganwa, A.A. and Toteu, S.F. (2006) Petrography and Géochemistry of the Ngaoundéré Pan-African Granitoïds in Central Nord Cameroon: Implication for Their Sources and Geological Setting. Journal of African Earth Sciences, 44, 511-529. https://doi.org/10.1016/j.jafrearsci.2005.11.017

[49] Djouka-Fonkwé, M.L., Schulz, B., Schüssler, U., Tchouankoué, J.P. and Nzolang, C. (2008) Geochemistry of the Bafoussam Pan-African I- and S-Type Granitoids in Western Cameroon. Journal of African Earth Sciences, 50, 148-167. https://doi.org/10.1016/j.jafrearsci.2007.09.015 